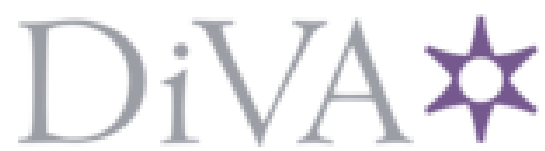

http://www.diva-portal.org

\title{
Postprint
}

This is the accepted version of a chapter published in Theoretical perspectives on family businesses.

Citation for the original published chapter:

Nilson, H. (2015)

Critical pedagogy theory and the family business.

In: Mattias Nordqvist, Leif Melin, Matthias Waldkirch and Gershon Kumeto (ed.), Theoretical perspectives on family businesses (pp. 211-232). Cheltenham: Edward Elgar Publishing https://doi.org/10.4337/9781783479665.00019

N.B. When citing this work, cite the original published chapter.

Permanent link to this version:

http://urn.kb.se/resolve?urn=urn:nbn:se:hj:diva-34247 


\section{Critical Pedagogy Theory and the Family Business}

\section{Henrietta Nilson}

\section{Introduction}

The family business can be viewed as a social construction surrounded by social limits as well as legal restrictions that tend to survive over time (Berger \& Luckmann, 1991). These restrictions cause limited situations (Freire 1970) for the family, which hinder them from living their lives fully and running their companies as would otherwise be possible. When considering the family dimension, it is important to reveal how these limits restrict and hinder possibilities, such as actions and expressions. To find puzzling phenomena, there must be a search for the underlying forces that are the primary issue behind the phenomena in question. Therefore, the researcher's theoretical standpoint should preferably be altered and accompanied by adequate research methods. A review of 235 samples of family business research publications, including empirical papers published in various academic journals between 1964-2010 and books/dissertations published between 1957-2010, reveals three dominant theoretical perspectives; principal-agent theory, stewardship theory, and resourcebased view theory (Siebels \& Knyphausen-Aufsess, 2012). To relate these publications to the 25 most-cited articles in family business research between 2003-2008, 12 out of 25 used principal-agent theory, and five used the resource-based view (Chrisman, Kellermanns, Chan \& Liano, 2010). This finding indicates that there is a lack of variety regarding theoretical viewpoints in family business research that could enable a more in-depth understanding of the family as well as the business dimension. Dawson (2014) notes that the next generation of family business scholars' primary theme is succession and topics relating to economic performance. Melin, Nordqvist and Sharma (2014) state that although topics, such as succession, governance, and performance, have widely been written about, they can still catch 
attention, but the interest of future research lies in developing a nuanced understanding of these issues (2014, p. 5). According to these authors, further attention is still needed to explain the underlying processes and phenomena. To understand themes, such as repression or relations of asymmetry, family business scholars should move away from the abovementioned dominant theoretical standpoints and instead move towards a critical stance. By adopting a critical theory perspective, it is possible to examine the underlying forces that shape businesses as well as families. These perspectives have been surprisingly absent in contemporary family business research, although a few exceptions can be found within gender studies in family business. One critical theory that has not been used is the concept of critical pedagogy by Paulo Freire (1970). Freire (1970) offered a critical pedagogical theory and a methodological way of understanding difficult and tabooed phenomena. Utilizing critical pedagogical theory, the family business, as well as the surrounding environment with its affecting restrictions, can be seen as limited situations (Freire, 1970) that influence family members in their everyday work in the family firm. By uncovering limited situations, the individual's consciousness can be changed towards a more critical standpoint, making it possible to 'see' possibilities that had previously been hidden; this, in turn, can lead to a shift in the doing of family business. The uniqueness of critical theory in general, and Freire's critical pedagogy theory more specifically, is the way in which the theory and the method unlock studies that have hitherto been nearly impossible to conduct (Hall \& Melin, 2012). The Freirean critical dialogue (1970) makes it possible to reveal forces, such as those mentioned. Based on the development within family business research, the aim with this chapter is therefore to present a novel view on family business research and on how a critical pedagogy perspective can unlock a close up study of the phenomenon of family business. The purpose is to use critical pedagogy to discuss family business from a limited situation perspective and to argue for a Freirean (1970) dialogue as a means of developing a critical consciousness for 
family members in the family business context. This chapter starts with an introduction to critical theory and its background. It then positions Paulo Freire within the critical theory era and outlines some of his primary philosophical thoughts; moreover, it addresses the connection between family businesses and critical theory. The chapter ends with some recommendations on how to use Freire's concept in a family business.

\section{Critical theory and its history}

This chapter uses Alvesson and Sköldberg’s description of critical theory as “[...] the tradition in social science which includes the Frankfurt school and its associated orientations and writers [...]” (2009, p. 144). Critical theory has its roots in the Frankfurt School's (Alvesson \& Sköldberg, 2009) focus on Marx’s capitalist exchange relations and subjectobject dialectics (Morrow \& Brown, 1994). Guiding principles include an emancipatory interest in knowledge, the asymmetries of power and how they can be subject to radical change and the assumption that social phenomena must always be viewed historically. The theoretical inspiration for this viewpoint stems not only from Marx but also from Weber, Kant, Hegel, and Freud (Alvesson \& Sköldberg, 2009); (Steffy \& Grimes, 1986). Habermas, one of the most imposing contemporary philosophers, is considered to belong to the second generation of the Frankfurt School theorists. During the 1960s, critical theory was marginalised by the older Frankfurt School for its negative posture against positivism (Morrow \& Brown, 1994). Habermas developed an independent critical theory that implicates decisions determined for objective reasons, free from manipulation and presented in an independent forum. The opposite is systematically distorted communication fuelled by power relations and influenced by mystifications, dishonesty, and misinformation (Alvesson \& Deetz, 2000). In his theory, Habermas also argued for the relationship between knowledge and the actual production of knowledge. According to Habermas, the polarisation and domination of hermeneutics and naturalism elicits forces that shape and distort consciousness 
(Morrow \& Brown, 1994). Habermas differentiated between three views of knowledge: technical, which is concerned with creation and nurturing survival, historical-hermeneutic, which addresses overcoming distances between individuals through interpretations of texts, gestures and statements, and emancipatory, which identifies sources of ideological notions and misunderstandings (Alvesson \& Sköldberg, 2009). Although critical theory has implications against hermeneutics, it belongs to the interpretive tradition and is often referred to as critical hermeneutics. The distinction between hermeneutics and critical theory is the interest in emancipatory knowledge, where unconscious as well as structural phenomena must be considered (Alvesson \& Sköldberg, 2009). Alvesson and Sköldberg (2009) described hermeneutics on three levels to get to the point where critical theory can be described. Called triple hermeneutics, it embraces simple hermeneutics (the individual's interpretation of their lived lives and the meaning created from their experiences) and double hermeneutics (scientists' interpretation of the above). Triple hermeneutics also includes interpretations of typical critical areas, such as power relations, expressions of dominance, ideologies and unconscious processes. Within philosophy, sociology, and educational research, critical theory has been widely used to debate, for instance, the relations of injustice and domination (Forst, 2001; Bernstein, 2005), the fundamental transformations in the world economy, politics, and culture (Kellner, 2002), and adult learning and education (Mezirow, 1981). With regard to research within organisations, critical theory has been found to be useful in generating new understanding of micro-politics in organisational work (Toegel, Kilduff \& Anan, 2013), analysing organisational science (Steffy \& Grimes, 1986), and broadening marketing channels for education, research and practice (Pelton, 2013). Critical theory has, moreover, been applied to extend entrepreneurship theory with the aim of encompassing social change. One example is Calás, Smircich and Bournes’ article on changing entrepreneurship’s analytical lens from “[...] economic phenomena in market societies” (2009, 
p. 552) to a feminist one. The authors problematise the dominant theoretical constructs and foreground the economic emphasis behind them that include groups, such as women, people of colour, and immigrants, among others. In another article, Berglund and Johansson (2007) address marginalisation and suppression vis-à-vis “[...] the ability for particular groups in society to view themselves as entrepreneurs [...]” (2007, p. 499). The authors adopted a Freirean perspective on entrepreneurship to show how the enterprise discourse suppresses an equality discourse in regional development. Because the Freirean perspective privileges individuals' consciousness rather than 'lending a helping hand' to the groups that do not consider themselves to be entrepreneurs, the article shows that transformation toward change via entrepreneurial capacity rests within all people. By that, Berglund and Johansson oppose the mobilisation of the few individuals who mirror themselves in the picture of the entrepreneur.

\section{Paulo Freire and critical pedagogy}

\subsection{Positioning Paulo Freire in critical theory}

Almost parallel with Habermas, Paulo Freire (1921-1997) introduced concepts of critical reflection (conscientização) before action (change) (Freire, 1970; 1974). His central idea was that reflection and language development can enable a personal self-critique wherein words give meaning to actions (Rönnerman, 2004) by eliciting structures that can be questioned for change (Freire, 1974). Freire's theoretical framework development has its roots in his upbringing.

He was born in 1921 in Recife, Brazil, and his early work in adult literacy began as experiments in the town of Angicos in Rio Grande do Norte; unfortunately, he was imprisoned during the military coup in 1964 (Mclaren \& De Lissovoy, 2002). Freire went into exile; in November of the same year, he arrived in Chile, where he started to work with adult 
literacy education (Kirkendall, 2004). During this period, he wrote his most important work, “Pedagogy of the Oppressed” (1970), which coincided with a time of intense debate over teaching, learning and schooling (Roberts, 2007a). Freire spent his final years teaching, writing, and reflecting (Roberts, 2007a). Freire’s work has come to be labelled critical pedagogy (Popkewitz \& Fendler, 1999), which represents both “[...] the analytical tradition of 'critical thinking' that considers the conceptual procedures of inquiry and specific belief claims in education [...]” (Burbule \& Berk, 1999, p. 9) as well as “[...] how systems of belief and action in schooling are embedded in systems of power and structural arrangements of society[...]” (1999, p. 9). This chapter adopts the latter meaning of critical pedagogy. Critical pedagogy stemming from the Frankfurt School and the interpretive traditions addresses educational efforts to create an “[...] equitable, democratic, and emancipatory society [...]” (1999, p.9). In contrast to Habermas, Freire can be positioned within the critical Marxist tradition, wherein Marx's early work is used to analyse the ideas and structures that shape the relationship between the individual and the society. In addition, Freire found inspiration through phenomenology and existentialism (Gottesman, 2010). Freire’s contribution to Marxian thought includes cultural and media influences and their impact on capitalist economic relations (Burbules \& Berk, 1999). To reveal the institutions that foster and reinforce such relations (1999, p. 50), Freire designated the existing educational system as banking education (Freire, 1970). His reflection on the system was a summary of the presupposed attitude to consider " [...] the teacher as the knowledgeable subject and the student as the ignorant object [...]" (Schugurensky, 1998). Freire’s primary point was to argue for the opposite as " [...] a dialogic relationship between teacher and student based on mutual learning and critical thinking [...]" (Freire, 1970). From this position, Freire urged students to engage in dialogue with the purpose of getting to know other people's experience and change the mood of consciousness (Freire, 1970; 1974). 


\subsection{Limited situations}

In everyday life, individuals are surrounded by limited situations (Freire 1970) that create obstacles to the full consciousness of a situation. In other words, individuals have limited consciousness in terms of how and in what way their surrounding environment affects their living and 'being'. In turn, this limitation can cause confusion about what and who is regulating the forces that influence everyday life. Freire’s (1970) concept of limited situations describes how recreations of culture shape historical epochs. People’s characteristic attitudes in a specific time help to shape themes that influence the epoch and flavour it with values, concepts, and ideas. Establishing epochs is a function of the possibilities inherent in selfexpression; that is, an epoch determines whether individuals can express themselves or not. Moreover, personal actions and an understanding of the themes determine whether an individual is a subject or an object and, by that, either an integrated or an adapted person in society. The themes are wrapped up in the so-called limited situations. What Freire (1970) meant is that there are pros and cons to limited situations depending on who is using or being used by them. Being used by a limited situation can be described as follows. The forces that determine the limited situation use it to rule other people without their knowledge, which of course gives the rulers an advantage. This situation can be compared to playing a game; knowing the rules creates an integrated person and not knowing the rules evokes a person in need of adaption. The limited situation restricts actions; beyond it, there is an untested possibility that can be seen as a threat or potential depending on the consciousness of the individual. 


\section{Dialogue - a way to reach critical consciousness}

\subsection{The meaning of dialogue}

According to Freire, to reveal limited situations, the individual's consciousness needs to be changed (1970) by using dialogue to build a platform where this can take place. The term “dialogue” stems from two Greek models, with the Socratic model representing a "mode of inquiry” that serves the purpose of discovering new ways of understanding (Linder, 2001, p. 653) and the Athenian model representing a "mode of will formation”, where bonds of culture as well as commitments are the primary issues (Linder, 2001, p. 655). In its simplest meaning, dialogue can be seen as a conversation between two or more persons (Gergen, McNamee \& Barrett, 2001, p. 681). From a Bakhtinean perspective, a distinction between dialogue and conversation can be illustrated by the difference in utterances that are made by the dialogical parts (Holquist, 1990). Utterances can in this situation be understood as “[...] a word or a sentence, spoken or written [...] infused with intentions” (Jabri, 2004, p. 570). The difference in utterances is the bond that holds together the dialogue relation; moreover, the dialogue is characterised by the relation that is manifested in the conversation (Holquist, 1990). However, dialogue is not only an aspect of improving collective thinking; instead, its linguistic tools can be used to position the individual in the conversation, which means, “[...] a way of being with others as opposed to a way of thinking through issues and problems [...]” (Barge \& Little, 2002, p. 377). The role of the communicating parts is therefore an aspect of dialogue that needs further attention considering that the dialogical aspect of communication is the shift between the roles of the sender and receiver of information (Blakar, 1992). Freire discussed how dialogue enables not only the questioning of class, ethnicity, and gender but also the identification of how knowledge is produced. The aim of dialogue is mutual understanding via knowledge exchange (Luke, 2012) and, moreover, the channelling of the 
evolution of consciousness (Roberts, 2007b),

“[...] dialogue characterises an epistemological relationship. Thus, in this sense, dialogue is a way of knowing and should never be viewed as a mere tactic to involve students in a particular task. We have to make this point very clear. I engage in dialogue not necessarily because I like the other person. I engage in dialogue because I recognise the social and not merely the individualistic character of the process of knowing. In this sense, dialogue presents itself as an indispensable component of the process of both learning and knowing.” (Freire, 1970, p. 17)

The difference between the Bakhtinean and the Freirean perspective on dialogue is a way of being versus a way of knowing. These perspectives share a belief that dialogue is a relational practice in which communication must also be viewed in its cultural and environmental context (Barge \& Little, 2002). There are three different areas of use into which dialogue can be categorised: transformative, ontological and everyday (Cooper, Chak, Cornish \& Gillespie, 2013). Transformative dialogue can be characterised by communication through deep knowledge, which leads to change and development; it also seeks possibilities for interpretation of the situation. The ontological view addresses dialogue as something fundamentally basic to human existence. Everyday dialogue is about social communication between human beings in everyday life. Freire takes on all three uses of dialogue and argues that transformative dialogue may be viewed as “[...] any form of interchange that succeeds in transforming a relationship between those committed to otherwise separate and antagonistic realities (and their related practices) to one in which common and solidifying realities are under construction” (Gergen et al., 2001, p. 682). From an ontological standpoint, Freire 
(1970) meant that people are beings of communication and that dialogue cultivates the development of consciousness, the process of dialogue helping us to become more fully human (Roberts, 2007b). Furthermore, in our everyday social life, language is used to communicate but also to teach and learn about the personal environment; moreover, language is the tool for inculcating self-expression. Dialogue can be interpreted in three stages: (1) predialogue, (2) dialogue and (3) post-dialogue. The first stage, pre-dialogue, is about circumstances that need to be fulfilled before dialogue can occur. The second stage is dialogue, which in this chapter is discussed from the Freirean perspective. The third and final stage is post-dialogue, which can be seen as an 'act' - in some cases, an inner act, such as critical consciousness and in others, a physical act, such as some sort of change. Each of these three stages is discussed in greater detail below.

\subsection{Pre-dialogue}

There are some prerequisites to dialogue, such as two parts that are equal and find an interest in naming the world; this means a mutual interest in developing and discussing words that both parts are interested in and want to learn about (Freire, 1970). Barge and Little (2002) also note the importance of the participants' will and argue that an invitation to a dialogical conversation per se does not necessarily lead to dialogue: on the contrary, it can be seen as an attempt to manipulate the individual. Platforms need to be built where dialogue can take place, such as common practices for conversations or using a story, which provide space for discussions about what explicitly is not talked about, such as values and worldview (Black, 2008; Boyd \& Markarian, 2011). Through a story, individuals are invited to a dialogic space that makes human interaction and sharing experiences possible (Black, 2008). Moreover, a dialogic space can also be seen as framing a context. Jabri (2004, p. 572) suggests that by interpreting utterances in a mutual process, possibilities occur for "transposing the meaning of one utterance into another”. The Bakhtinean view on dialogue, however, suggests that “all 
conversation among people is dialogic” (Barge \& Little, 2002, p. 385 ) and that a dialogic practice is dependent on the situation. The participants in the conversation establish a relationship, which, according to Bakhtin's dialogism, is fundamental to the process of exchange (Holquist, 1990). Speech, words, and dialogue flourish in a supporting environment where the participants are able to expand their boundaries (Boyd \& Markarian, 2011), and according to Voloshinov (Barge \& Little, 2002), the use of words and expressions to organise experience is important. Freire expanded this discussion when he questioned an individual's ability to use words for expressions and highlighted the significance of actually having a vocabulary. As one of Freire’s students stated, “[...] all my life I felt the things you talked about. I just didn’t have a language to express what I have felt” (1970, p. 22 ). Creating dialogue is, in the Freirean sense, a way to build up language that enables self-expression (Freire, 1970).

\subsection{Dialogue}

Because people create their existence via language, dialogue creates trust when actions are equal to the true word, that is, what is said is also what is done (Freire, 1970; Boyd \& Markarian, 2011). In the reading of Freire, the true word is said in the dialogue followed by action in the post-dialogue. A corporate platform is created when both parties' view of the world is discussed and dialogue is created in the moment. When both parts become equally aware of each other, the outcome can be considered to be a dialogic moment (Cissna \& Anderson, 1998, p. 74).

"The basic character of such a dialogic moment, therefore, is the experience of inventive surprise shared by the dialogic partners as each 'turns toward' the other and both mutually perceive the impact of each other's turning. It is a brief interlude of focused awareness and acceptance of otherness and difference that somehow simultaneously transcends the perception of difference itself.” 
Dialogue makes sharing experience and identity confirmation possible (Boyd \& Markarian, 2011). It can also, in a Bakhtinean way, be characterised by the sharing of consciousness between the dialogical parts: “[...] a person’s consciousness awakens wrapped in another’s consciousness” (Jabri, 2004, p. 569). The unique conversational moment also emphasises ethical choices; in other words, participating in dialogue demands an understanding of the discourse as well as the specific setting in time (Barge \& Little, 2002). Freire’s (1970) use of dialogue embraces discourse in that the setting is the participant's environment; furthermore, the discussions circulate around the participants' everyday work and life (Freire, 1970).

\subsection{Post-dialogue}

There is no dialogue without words. The word has, according to Freire (1970), a two-fold dimension: reflection and action. Once named, a phenomenon needs to be problematised and renamed in an ongoing process: a dialogue. A true word is always followed by action; from the affectionate surrounding of dialogue, the true word appears and cultivates consciousness. Furthermore, the true word creates a will to change and reshape the individual's world (Freire, 1970). For example, Boyd and Markarian (2011, p. 523) showed in their empirical study that "literate talk leads to literate writing" - the area of discussion leads to new consciousness that is followed by an act, in this case literate writing. In Black’s (2008) article, however, dialogic moments produce conditions for creating a collective identity, which leads to a deeper understanding of others. In the latter example, the 'act' is not physical, but rather an inner 'act' that the individual can bring forth in future situations. Even in the Bakhtinean perspective of dialogue, there appears to be a post-dialogue. Via the conversational situation, possibilities open up for “[...] living a new pattern of communication [...]” (Barge \& Little, 2002, p. 390 ); through other people’s experience and their different stories, the participants become embodied in new ways of communication. 


\section{Towards critical consciousness}

The untested possibility beyond the limited situation is hard to reveal when the individual's consciousness is limited (Freire, 1970). The purpose of creating platforms where the individual can change their consciousness is then to go beyond real consciousness to reach the potential consciousness that eventually culminates in critical consciousness. If consciousness according to Vieira (Freire, 1970) is to be considered as a method, dialogue is the platform where the consciousness can be changed. The essence of ever-changing human consciousness can be described as follows:

“[...] being with the world, and this behaviour is permanent and unavoidable.

Accordingly, consciousness is in essence a way towards something apart from itself, outside itself, which surrounds it and which it apprehends by means of its ideational capacity. Consciousness is thus by definition a method, in the most general sense of the word.” (Freire, 1970, p.69)

In the research process, one way to methodologically start the process of making a change in individual consciousness possible is to create a pre-dialogue stage by asking participants to tell a story, such as a life story (Johansson, 2005). When the researcher’s interpretation (for example, using words similar to (in)visibility (Nilson, forthcoming)) is handed to the participants to read, their real consciousness is challenged. If the researcher then discusses the story with the participant, two worldviews meet. In the discussion, the participants' consciousness is mirrored in the researcher's new story of their lived experience, which puts their real consciousness in a new light. Two worldviews are metaphorically "colliding” and a potential consciousness within the participant takes shape. 
(Figure 12.1)

The participants involved discover two modes of reality (the original versus the new) as well as two modes of consciousness, the former real consciousness and the new potential consciousness. When the parts view their reality from these two perspectives, something is happening; they view their former reality in the light of their new reality as discussed in the dialogue. The experience from the two different modes creates a divergence within the individual, yet a process is starting that could lead to critical consciousness. The process makes changes possible; Freire (1974) defines this learning as conscientização. "The term conscientização refers to learning to perceive social, political, and economic contradictions, and to take action against the oppressive elements of reality [...] it represents the development of the awakening of critical awareness." (Freire, 1974, p. 15)

(Figure 12.2)

With his work, Freire was aiming to create a common ground for people to change their consciousness and by that, also, to change their world. By learning to read and write (during 
the illiteracy training he was responsible for), participants could question authority and redefine their own naive and mysterious reality (Freire, 1970). The contribution to Marx’s revolutionary theory was mentioned earlier; in addition, the change of consciousness leads participants to understand their position within the social order and to create building blocks for radical social change (Gottesman, 2010). Even from the Bakhtinean perspective, dialogue provides possibilities for individual change and empowerment (Jabri, 2004), but although the transition of consciousness does not necessarily lead to transformation, it is the key to liberation according to Freire (Schugurensky, 1998).

\section{Critical theory and its rare connection to family business}

Even if family businesses predominate in the world economy, the understanding of how structures and practices produce relations of power or asymmetry is lacking (Fletcher, 2014). Although family business as a research field has come to a certain state of maturity, the connection to critical theory is very limited. One example of an area that has been highlighted is the female gender perspective on phenomena, such as visibility versus invisibility ((in)visibility) (Gillis-Donovan \& Moynihan-Bradt, 1990; Hollander \& Bukowitz, 1990; Cole, 1997; Curimbaba, 2002; Vera \& Dean, 2005; Hamilton, 2006; Barrett \& Moores, 2009; Jimenez, 2009). The studies conducted on this topic reveal underlying forces of how women in family businesses are experiencing (in)visibility in their everyday work in the family firm. For example, research has shown that in situations where the family as well as business relations ignore the capacity of women in family firms, feelings of invisibility emerge (Cole, 1997). The succession process has been discussed as an issue for daughters in family firms (Sentuti, 2009; Wang, 2010), and even in situations where the mother is operating as CEO, daughters are affected by feelings of invisibility, predominantly from co-workers’ comparisons but also from the mothers' resistance to sharing power (Vera \& Dean, 2005). Furthermore, women in family businesses have a tendency to preserve ruling gender roles by 
valuing their husbands' behaviour less when acting contrary to a masculine manner. These women also try to become visible by accentuating their feminine side instead of highlighting their professional experience (Curimbaba, 2002). By looking at these examples through a critical lens, a question is whether a phenomenon, such as (in)visibility, is only a female gender issue or if it is a far more complicated situation where “[...] a stronger critical (ethical and political) dimension is important for family business inquiry, not only to highlight the specifics of women in business but also to reveal (and reduce) the barriers that inhibit female participation in family business and to demonstrate the production of gendered patterns (Fletcher, 2014, p. 141)”. From a critical point of view, the female gender perspective is only one way of looking at phenomena, such as (in)visibility. Moreover, by revealing the actual power of women in family business, Fletcher's abovementioned female participation can be scrutinised from angles other than gender. What these examples show is that women, as well as academia, are participants in gendered pattern reproduction. Even in Hamilton’s (2006) study of women's roles in establishing family firms, the discussion circulates around resistance to patriarchy, which in a critical view can be challenged. Why not view these actions as evidence of matriarchy? Through the use of gendered words and thoughts, it can be questioned how family business research still reproduces the picture of women as 'invisible victims' in family firms. Though this is a provocative notion, Fletcher's argument for viewing family business research via a critical social science nonetheless says that it "[...] enables research attention to be drawn to alternative viewpoints or perspectives and routines/practices that do not affirm what is known about family firms but which focus on efforts to circumvent, disrupt or destabilise (Fletcher, 2014, p. 149).” (For a more in-depth view on gender theory, please read Karin Staffansson Pauli's chapter in this book.) These examples show that critical theory is rarely used in family business research, while the Freirean critical pedagogy is conspicuous by its absence. To note what several authors have argued, the critical pedagogy 
perspective can open up a totally new area of research that enables understanding of family business in several ways. Using a critical standpoint can complement the current studies and potentially problematise phenomena, such as (in)visibility, in a way that shows the complexity of family firm surroundings (Nilson, forthcoming).

\section{Understanding family business as limited situations}

If family business is regarded as a social construction (Berger \& Luckmann, 1991; Barlebo Wenneberg, 2000), the family business unit itself can be seen as a limited situation (Freire, 1970), which makes it a problem to consider an outside, untested possibility. As already discussed, family business has for decades been affected by social values, norms and legal restrictions (Pettersson, 2002) that persist in the doing of family business. If the limited situation is challenged, consciousness can change, providing an opportunity for the individual family member to see possibilities outside of the family business’ boundaries (Freire, 1970). What are the limited situations that family businesses of today struggle with? An example of such a limited situation can be described in the light of law. Law has had a great impact on the work within family firms, particularly as it pertains to restrictions about human effort (women and children) and ownership for women in family firms. In previous centuries, women where restricted from owning businesses, as well as from officially working within their family firms (Karlsson Stider, 2000) (Pettersson, 2002; Bersbo, 2012); nevertheless, they worked behind the scenes and had to stay socially invisible. Despite legal shifts, old ways of thinking still influence decision making. One example is in the succession process, where sons remain favoured (Curimbaba, 2002; Sentuti, 2009). Restriction of ownership can be seen as one way of socially objectifying family members, and even though the family members’ individual business achievement was needed, the family still had to follow the regulatory system at the time, the legacy of which persists (Miller, Steier \& Le Breton-Miller, 2003). Furthermore, academia still portrays women in family businesses as invisible, despite social and legal 
changes. Another example of a limited situation can be found in the process of succession. To relate to Dawson's (2014) findings that succession is an important upcoming topic for research, Long and Chrisman (2014) claimed that understanding succession management in family firms can still be developed in several different areas, for instance, how culture affects “a family’s understanding and expectations of the succession process” (2014, p. 259), how specific words and definitions are influenced by the culture in which they are embedded, and how conflict and harmony can be encouraged or mitigated in the succession process. One area that has caught some attention pertains to roles and potential goal conflicts in family business (Siebels \& Knyphausen-Aufsess, 2012). From a critical point of view away from female gender issues, the succession process has implications for limited situations. Succession processes are influenced on levels other than the problem of who the successor will be, and one such problem is the transfer of knowledge between family members in the firm. To achieve success in a family business, there is a crucial point at which there must be a mutual interest in learning and sharing knowledge between the predecessor and the successor (Chirico, 2008). In this case, the limited situations can emerge as a result of resistance from both parts toward engaging in such a process. Moreover, the managing director's vision and knowledge transfer is often the single voice that finds its way to the rest of the family or employees during the succession process (Giovannoni, Maraghini \& Riccaboni, 2011). It can be said that 'Banking education', where the teacher is considered to be the knowledgeable subject and the student to be the ignorant object (Freire, 1970), is far from unusual in family firms, hanging on, such as a social leftover from old times, mores and familiar habits, especially from the older generation (Chirico, 2008). Objectifying family members in this way can also negatively influence the coming generations, and retaining the banking education system can prevent the mutual transfer of knowledge and hinder the successful survival of a family business over generations (Chirico, 2008). Looking at knowledge from a 
critical point of view, the issue is whose knowledge is represented and transferred and who takes advantage of this representation. Power can be found in both the predecessor's and the successor's role. In the family business context, power relations start to work from both ends, which means that transferring as well as ignoring the transfer of knowledge are ways of addressing power (Schultze \& Stabell, 2004). What Freire (1970) argues for is the mutual learning and transfer of knowledge. Nevertheless, academia still favours the banking view by not highlighting the mutual learning between generations (Giovannoni et al., 2011; Märk, 2012).

\subsection{Methodological issues}

To understand underlying processes (Dawson, 2014), methods must explore the taken-forgranted nature of organisational life (Cunliffe, 2002); furthermore, they must reveal not only what is said but also what is not said (Cunliffe, 2003). To achieve this understanding, Cunliffe (2002) provided an example of a participative process that accepts research as socially constructed and suggests working with metaphors to enable the creation of strong impressions and feelings about a specific situation. By self-videotaping conversations with a participant and then watching them together, Cunliffe (2002) shows how mutual understanding and meaning is possible between researcher and participant. "Together, researcher and participant focus on how a shared sense of the situation unfolds in the responsive, interactive moments in the research conversation”(Cunliffe, 2002, p. 997 ). A multi-faceted view (the entire family) of the business in question creates a deeper understanding of the underlying

forces (Johansson, 2005), so when researching the family firm, all family members who are active in the firm can tell their about their lived experience in the family business. This research process can be performed, for instance, in a dialogue by introducing terms, such as (in)visibility in a surprising way (Cissna \& Anderson, 1998). Through this process, the participants can learn not only about contradictions within the family dynamics (social) but 
also about underlying contradictions (economic and political) that mould and reproduce oppressive elements within the family firm context (Freire, 1970). Revealing these contradictions provides an opportunity for family members to themselves take action against, or at least be conscious of, the limited situations that affect the family. Furthermore, they can figure out the lifelong consequences for the business.

\subsection{The role of the researcher}

The participative critical research method, as in Freire's (1970) case, is special in the sense of the researcher's involvement. The researcher is far from objective; on the contrary, the research situation is constructed, created, initiated, and staged (Johannisson, 2005). The aim of this approach is to create prerequisites for attendants to change their consciousness without - for the sake of the researcher - having the responsibility for actual change in the firm (Steffy \& Grimes, 1986; Johansson, 2008). Therefore, the researcher’s aim is to create space for a transformative revaluation (Alvesson \& Deetz, 2000) where the attendants can be enlightened about where the actual primary control of power is. By creatively using methods, such as those mentioned, the researcher can dig deeper under the surface, which is usually hard to penetrate. Furthermore, these methods offers possibilities for attendants to express inner feelings and thoughts that are rarely elicited by traditional methods (Kostera, 2007).

\subsection{The publishing issue}

This methodological approach can be challenging, especially for the new generation of family business researchers. Dawson (2014) problematised the issue of original researchers introducing new constructs; she also exposed the overall publishing issue that leads scholars to prefer playing it safe, which inhibits novel methodological thinking. Dawson’s suggestion is that family business research needs in-depth case studies that can support the understanding 
of human behaviour and adopt a critical stance. All of the above-mentioned suggestions highlight the importance of looking further to examine the family business social world. Therefore, adapting to a critical standpoint involves problematising the obvious issues in family firms (Alvesson \& Deetz, 2000) and allowing the critical perspective to destabilise the assumptions made within earlier research (Freire, 1974).

\subsection{Platforms and untested possibilities}

The discussion in this chapter has revolved around Freire's (1970) argument for creating platforms or common ground on which dialogue and the raising of consciousness can occur. In everyday work, some natural spaces can fill the purpose of these platforms, and one such space is the socialisation process, where the older generation educates the younger, incoming one. The challenge is to find a pre-dialogic environment that supports the dialogic moment by allowing family members to expand their boundaries and have an equal interest in naming the world. Platforms can be created, for example, by making space for educational situations, where Freire's (1970) notion on dialogue and view of the teacher as the student - the student as the teacher, can be embraced. This is a concept that can open up possibilities for interesting learning transfer and can bring multidimensional knowledge into a family firm. What is proposed here is that the possible effect of dialogue in the form of interest, enthusiasm and will towards engaging in a family firm is consistent with post-dialogue, where the true word is always followed by action. The will to change and reshape can bring economic and personal welfare to the business. With regard to the discussion on platforms, untested possibilities are also issues that are highlighted in this chapter. What untested possibilities can emerge from using Freire’s (1970) philosophical thoughts in family business? As mentioned above, opening up ways to transfer knowledge in a mutual way can reveal the underlying forces of actions that make it possible to see untested possibilities beyond the limitations that family firms are enacting. Such possibilities can, for instance, be hidden 
knowledge that was earlier wrapped up by the banking way of educating incomers to the family firm. As Siebels and Knyphausen-Aufsess (2012) noted, little attention has been given to roles in family businesses, and by embracing Freire's notion of critical consciousness, the change that can occur opens up different ways of looking at roles. Family members can, in their establishment role, be wrapped up in traditional ways of thinking about role distribution. To tackle the problem of role insecurity, or the consciousness of limitations, roles can be changed. Socially, legally and politically given roles can be challenged and disrupted, and new roles can be established on grounds, such as interest, capacity, knowledge and skills, that instead reinforce the will to work within, as well as to take over, the firm when the time comes. Reflection and consciousness are intertwined in dialogue, and consciousness can be developed into critical consciousness, which, according to Freire (1970), always leads to action. Dialogue opens up areas different from banking education (Freire, 1970) in that it can change the family's view on the environment and the world within which the family business exists. Words also fill different purposes, such as enabling the expression of a situation, a feeling, or an experience. The limited situation of the family business can also be a limited situation of words that prevent experiences from being expressed (Schuetz, 1953); it can be said that dialogue gives words a condition for unwrapping experiences and a language with which to express them. If family members have the opportunity to express themselves and to change modes of consciousness, as well as reality, some thrilling questions occur: what happens to family members and what do they do in the family business? With several points of view, these questions not only can change the interaction and understanding between generations in family firms but also open up a new business landscape (Normann, 2001) where the untested possibility can be revealed (Nilson, forthcoming). By ending this chapter in a Freirean way, I present some final comments from a family business member who has been wrapped up in a limited situation. She changed her consciousness through a dialogue 
but, primarily, found untested possibilities that lead to an emancipatory post-dialogical act (Nilson, forthcoming).

“Now I am visible and I know that I have the knowledge, I didn’t know that before [...] [Laughs] All my clothes had the colour of beige, now I have changed the wardrobe into colourful pieces in orange and red [...] Since I built the studio a lot of people from the village have been visiting me asking what I am doing I’m running my own business now.” 


\section{References}

Alvesson, M. and Deetz, S. (2000), Kritisk samhällsvetenskaplig metod, Lund, Sweden: Studentlitteratur.

Alvesson, M. and Sköldberg, K. (2009), Reflexive Methodology, London: Sage.

Barge, K. J. and Little, M. (2002), 'Dialogical wisdom, communicative practice, and organizational life', Communication Theory, 12 (4), 375-97.

Barlebo Wenneberg, S. (2000), Socilalkonstruktivism - Positioner, problem och perspektiv, Malmö, Sweden Liber AB.

Barrett, M. and Moores, K. (2009), Strategic Invisibility: A Female Approach to Building Familiness, paper presented at EIASM Family Business Workshop, Belgium.

Berger, P. and Luckmann, T. (1991), The Social Construction of Reality: A Treatise in the Sociolgy of Knowledge, London: Penguin Books.

Berglund, K. and Johansson, W. A. (2007), 'Entrepreneurship, discourses and conscientization in processes of regional development', Entrepreneurship and Regional Development, 19, 499-525.

Bernstein, J. (2005), 'Suffering injustice: misrecognition as moral injury in critical theory', International Journal of Philosophical Studies, 13 (3), 303-24.

Bersbo, Z. (2012),. Rätt för kvinnan att blifva människa - full och helt, svenska kvinnors ekonomiska medborgarskap 1921-1971, PhD, (dissertation?) Växjö, Sweden: Linnaeus University Press.

Black, L. (2008), 'Deliberation, storytelling and dialogic moments', Communication Theory, 18, 93-116. 
Blakar, R. M. (1992). 'Towards an identification of preconditions for communication', in Wold, A. (ed.), The Dialogical Alternative Towards a Theory of Language and Mind, Oslo: Scandinavian University Press.

Boyd, M. P. and Markarian, W. (2011), 'Dialogic teaching: talk in service of a dialogic stance', Language and Education, 25 (6), 515-34.

Burbules, N. and Berk, R. (1999). 'Critical thinking and critical pedagogy: relations, differences, and limits', in Popkewitz, T. and Fendler, L. (eds), Critical Theories in Education Changing Terrains of Knowledge and Politics, New York: Routledge.

Calás, M., Smircich, L. and Bourne, K. (2009), 'Extending the boundaries: reframing entrepreneurship as social change through feminist perspectives', Academy of Management Review, 34 (3), 552-69.

Chirico, F. (2008), 'The creation, sharing and transfer of knowledge in family business', Journal of Small Business and Entrepreneurship, 21 (4), 413-33.

Chrisman, J. J., Kellermanns, F. W., Chan, C. K. and Liano, K. (2010), 'Intellectual foundations of current research in family business: an identification and review of 25 influential articles', Family Business Review, 23 (9), 9-26.

Cissna, K. N. and Anderson, R. (1998), 'Theorizing about dialogic moments: the BuberRogers position and postmodern themes', Communication Theory, 8, 63-104.

Cole, P. M. (1997), 'Women in family business', Family Business Review, 10 (4), 353-71.

Cooper, M., Chak, A., Cornish, F. and Gillespie, A. (2013), 'Dialogue, bridging personal, community and social transformation', Journal of Humanistic Psychology, 53 (1), 70 93. 
Cunliffe, A. L. (2002), 'Social poetics as management inquiry a dialogical approach', Journal of Mangagement Inquiry, 11 (2), 128-46.

Cunliffe, A. L. (2003), 'Reflexive inquiry in organizational research: questions and possibilities', Human Relations, 56 (8), 983-1003.

Curimbaba, F. (2002), 'The dynamics of women’s roles as family business manager', Family Business Review, 15 (3), 239-52.

Dawson, A. (2014), 'A look into the future: what is the next generation of family business scholars focusing on?', in Melin, L., Nordqvist, M. and Sharma, P. (eds), The SAGE Handbook of Family Business 1st edn, Thousand Oaks, CA: SAGE, pp. 629-31.

Fletcher, D. (2014), 'Family business inquiry as a critical social science', in Melin, L., Nordqvist, M. and Sharma, P. (eds), The SAGE Handbook of Family Business 1st edn, Thousand Oaks, CA: SAGE, pp. 137-54.

Forst, R. (2001), 'Towards a critical theory of transnational justice', Metaphilosophy, 32 (1-2), $160-79$.

Freire, P. (1970), Pedagogy of the Oppressed, New York: Continuum International Publishing Group.

Freire, P. (1974), Education for Critical Consciousness, New York: Continuum International Publishing Group.

Gergen, K. J., McNamee, S. and Barrett, F. J. (2001), 'Toward transformative dialogue', International Journal of Public Administration, 24 (7-8), 679-707.

Gillis-Donovan, J. and Moynihan-Bradt, C. (1990), 'The power of invisible women in the family business', Family Business Review, 3, 153-67. 
Giovannoni, E., Maraghini, M. P. and Riccaboni, A. (2011), 'Transmitting knowledge across generations: the role of management accounting practices', Family Business Review, 24 (2), 126-50.

Gottesman, I. (2010), 'Sitting in the waiting room: Paulo Freire and the critical turn in the field of education', Educational Studies, 46, 376-99.

Hall, A. and Melin, L. (eds) (2012), Ägarskiftet som ett relationsdrama, in Brundin, E., Johansson, A. W. Johannisson, B., Melin, L. and Nordqvist, M. (eds), Familjeföretagande: affärer och känslor, Stockholm: SNS Förlag.

Hamilton, E. (2006), 'Whose story is it anyway? Narrative accounts of the role of women in founding and establishing family business', International Small Business Journal, 24, $253-71$.

Hollander, B. S. and Bukowitz, W. R. (1990), 'Women, family culture and family business', Family Business Review, 3 (2), 139-51.

Holquist, M. (1990), Dialogism Bakhtin and his World, London; New York: Routledge.

Jabri, M. (2004), 'Change as shifting identitities: a dialogic perspective', Journal of Organizational Change Management, 17 (6), 566-77.

Jimenez, R. (2009), 'Research on women in family firms, current status and future directions', Family Business Review, 22 (1), 53-64.

Johannisson, B. (2005), Entreprenöskapets väsen, Lund, Sweden: Studentlitteratur.

Johansson, A. (2005), Narrativ teori och metod, med livsberättelsen i fokus, Lund, Sweden: Studentlitteratur. 
Johansson, W. A. (eds) (2008). 'Kritisk reflektion och handling i interaktiv forskning', in Gunnarsson, E., Johannisson, B. and Stjernberg, T. Gemensamt kunskapande - den interaktiva forskningens praktik, Växjö: Växjö University Press.

Karlsson Stider, A. (2000), Familjen och firman, Stockholm: Ekonomiska forskningsinstitutet vid handelshögskolan.

Kellner, D. (2002), 'Theorizing globalization', Sociological Theory, 20 (3), 285-305.

Kirkendall, A. (2004), 'Paulo Freire, Eduardo Frei, literacy training and the politics of consciousness raising in Chile, 1964 to 1970', Journal of Latin American Studies, 36 (4), 687-717.

Kostera, M. (2007), Organisational Ethnography Methods and Inspirations, Lund, Sweden: Studentlitteratur.

Linder, S. (2001), 'An inquiry into dialogue, its challenges and justification', International Journal of Public Administration, 24 (7-8), 651-78.

Long, R. G. and Chrisman, J. J. (eds) (2014), Management Succession in Family Business, London: Sage.

Luke, A. (2012), 'Critical literacy: foundational notes', Theory into Practice, 51, 4-11.

Märk, S. (2012), 'The transfer of knowledge within the succession process of family businesses: results from a quantitative study in Western-Austria', International Journal of Entrepreneurship and Small Business, 17 (2), 176-98.

Mclaren, P. and De Lissovoy, N. (eds) (2002), Cengage Learning, 2nd edn, vol. 3,, New York: Macmillan. 
Melin, L., Nordqvist, M. and Sharma, P. (2014), The SAGE Handbook of Family Business, London: Sage.

Mezirow, J. (1981), 'A critical-theory of adult learning and education', Adult Education, 32 (1), 3-24.

Miller, D., Steier, L. and Le Breton-Miller, I. (2003), 'Lost in time: Intergenerational succession, change and failure in family business', Journal of Business Venturing, 18, $513-31$.

Morrow, R. and Brown, D. D. (1994), Critical Theory and Methodology, Thousand Oaks, CA: Sage.

Nilson, H. (forthcoming). Talk about Being (In)Visible, Växjö, Sweden: Linneaus University.

Normann, R. (2001), Refraiming Business: When the Map Changes the Landscape, Chichester: Wiley.

Pelton, L. E. (2013), 'Critical social theory and the emancipation of marketing channels knowledge', Journal of Marketing Channels, 20, 204-23.

Pettersson, K. (2002), Företagande män och osynliggjorda kvinnor, Uppsala, Sweden: University Printers.

Popkewitz, T. S. and Fendler, L. (1999), Critical Theories in Education: Changing Terrains of Knowledge and Politics, New York: Routledge.

Roberts, P. (2007a), 'Conscientisation in Castalia: a reading of Herman Hesse's The Glass Bead Game', Studies of Philosophical Education, 26, 509-23.

Roberts, P. (2007b), 'Ten years on: engaging the work of Paulo Freire in the 21st century', Studies of Philosophical Education, 26, 505-8. 
Rönnerman, Karin (ed.) (2004), Aktionsforskning i praktiken, Lund, Sweden:

Studentlitteratur.

Schuetz, A. (1953), 'Common-sense and scientific interpretation of human action', Philosophy and Phenomenological Research, 14 (1), 1-38.

Schugurensky, D. (1998), 'The legacy of Paulo Freire: a critical review of his contributions', Convergence, 31 (1/2), 17-29.

Schultze, U. and Stabell, C. (2004), 'Knowing what you don't know? Discourses and contradictions in knowledge management research', Journal of Management Studies, 41 (4), 549-73.

Sentuti, A. (2009), 'The other side of succession. Female entrepeneurs and the intergenerational transfer in small and medium family-owned firms: some Italian empirical evidence', presentation at EIASM - 5th Workshop, Research on Management Practices in Family Firms, Hasselt, Belgium.

Siebels, J.-F. and Knyphausen-Aufsess, D. Z. (2012), 'A review of theory in family business research: the implications for corporate governance', International Journal of Management Reviews, 14, 280-304.

Steffy, B. D. and Grimes, A. J. (1986), 'A critical theory of organization science', Academy of Management Review, 11 (2), 322-36.

Toegel, G., Kilduff, M. and Anan, N. (2013), 'Emotion helping by managers: an emergent understanding of discrepant role expectations and outcomes', Academy of Management Journal, 56 (2), 334-57.

Vera, C. and Dean, M. (2005), 'An examination of the challenges daughters face in family business succession', Family Business Review, 18, 321-45. 
Wang, C. (2010), 'Daughter exclusion in family business succession: a review of the literature', Journal of Family and Economic Issues, 31 (4), 475-84. 
Figure 12.1: Towards critical consciousness

Real consciousness $\longrightarrow$ Potential consciousness $\longrightarrow$ Critical consciousness

Figure 12.2: Two modes of realities and consciousness
$\mathrm{RC}$
PC
Towards CC
Original reality
New reality
Divergence 